\title{
Biomass harvest of invasive Typha promotes plant diversity in a Great Lakes coastal wetland
}

\author{
Shane C. Lishawa ${ }^{1,2,3}$, Beth A. Lawrence ${ }^{4,2}$, Dennis A. Albert ${ }^{5,2}$, Nancy C. Tuchman ${ }^{1,2}$
}

Ecological and financial constraints limit restoration efforts, preventing the achievement of desired ecological outcomes. Harvesting invasive plant biomass for bioenergy has the potential to reduce feedback mechanisms that sustain invasion, while alleviating financial limitations. Typha $\times$ glauca is a highly productive invasive wetland plant that reduces plant diversity, alters ecological functioning, its impacts increase with time, and is a suitable feedstock for bioenergy. We sought to determine ecological effects of Typha utilization for bioenergy in a Great Lakes coastal wetland by testing plant community responses to harvest-restoration treatments in stands of 2 age classes and assessing community resilience through a seed bank study. Belowground harvesting increased light penetration, diversity, and richness and decreased Typha dominance and biomass in both years post-treatment. Aboveground harvesting increased light and reduced Typha biomass in post-year 1 and in post-year 2 , increased diversity and richness and decreased Typh $a$ dominance. Seed bank analysis revealed that young stands $(<20$ years) had greater diversity, richness, seedling density, and floristic quality than old stands ( $>30$ years). In the field, stand-age did not affect diversity or Typha dominance, but old stands had greater Typha biomass and slightly higher richness following harvest. Harvesting Typha achieved at least 2 desirable ecological outcomes: reducing Typha dominance and increasing native plant diversity. Younger stands had greater potential for native recovery, indicated by more diverse seed banks. In similar degraded wetlands, a single harvest of Typha biomass would likely result in significant biodiversity and habitat improvements, with the potential to double plant species richness.

Key words: biodiversity, biomass energy, conservation, hybrid cattail, Lake Huron, seed bank

\section{Implications for Practice}

- Both aboveground and belowground harvest of Typha stands increased plant diversity and richness for 2 years following treatment, indicating that these passive restoration methods (without planting) are viable in northern Great Lakes coastal wetlands with relatively intact seed banks.

- Younger Typha stands had a more intact and diverse seed bank than older stands.

- Harvesting Typha biomass for bioenergy production may be an appropriate alternative to herbiciding and burning methods in Great Lakes wetlands.

\section{Introduction}

The extent and intensity of ecological restoration is limited by ecological and financial constraints (Miller \& Hobbs 2007). A degraded ecosystem reaching an alternate stable state becomes resistant to restoration efforts or requires significantly more intense management to overcome ecological thresholds (Suding et al. 2004; Zedler 2009). Dominant invasive wetland plants can drive an ecosystem into an alternate state by causing significant changes to soil nutrients and carbon (Tuchman et al. 2009) and depleting native seed banks (Frieswyk \& Zedler 2006; Hall \& Zedler 2010). These environmental changes may correspond with the length of time that invaders have been established (Strayer et al. 2006; Mitchell et al. 2011). We predict that plant community responses to restoration efforts will depend in part upon invasive species residence time and that time since establishment can be a useful proxy for an ecosystem's restorability.

Harvesting invasive plant biomass could reduce feedback mechanisms that sustain the invaded state (Zedler 2009). For example, periodic removal of dense litter and aboveground biomass from invaded wetlands could simultaneously remove nutrient-rich plant tissue, increase light penetration to the soil surface, and increase plant diversity. In addition to the ecological potential of harvesting, utilization of invasive plant and other biomass residues for energy production could directly offset restoration costs (Quinn et al. 2013), thereby reducing

\footnotetext{
Author contributions: SL, DA, NT conceived the idea; SL, DA, NT, BL designed the experiments and sampling protocols; DA provided taxonomic expertise; SL, BL performed the experiments and managed data; SL analyzed the data and wrote the manuscript; BL, DA, NT edited the manuscript.

${ }^{1}$ Loyola University Chicago, Institute of Environmental Sustainability, Chicago, IL 60660, U.S.A.

${ }^{2}$ University of Michigan Biological Station, Pellston, MI 49769, U.S.A.

3 Address correspondence to S.C. Lishawa, email slishawa@luc.edu

${ }^{4}$ DePaul University, Environmental Science and Studies, Chicago, IL 60604 U.S.A.

${ }^{5}$ Department of Horticulture, Oregon State University, Corvallis, OR 97331, U.S.A.

(C) 2015 Society for Ecological Restoration

doi: $10.1111 /$ rec.12167

Supporting information at:

http://onlinelibrary.wiley.com/doi/10.1111/rec.12167/suppinfo
} 
the financial constraints on restoration activities. For instance, Nackley et al. (2013) illustrated that within a 1.1 million hectare fuelshed around a biomass power facility in Washington, the use of invasive shrubs for energy would entirely offset restoration, harvesting, and biomass transportation costs. In other regions, highly productive invasive plants have similar potential to serve as biomass fuel stocks (Jakubowski et al. 2010; Quinn et al. 2013).

Cattails (Typha spp.) have long been considered as possible bioenergy crops due to their high productivity, the potential for harvest to remove nutrients from polluted lakes and wetlands, and recently for the generation of carbon credits (Dubbe et al. 1988; Cicek et al. 2006; Grosshans et al. 2012). In eastern North America, Typha $\times$ glauca, an invasive hybrid between native Typha latifolia and invasive T. angustifolia (Smith 1987), may be an appropriate species for bioenergy production linked with ecological restoration because of high productivity, undesirable ecological impacts (Tuchman et al. 2009), and the potential for harvesting to restore ecosystem structure and function. Harvesting of $T . \times$ glauca's congener, $T$. domingensis, maintains biodiversity in central Mexican wetlands (Hall et al. 2008), and repeated $T$. $\times$ glauca harvesting resulted in increased native graminoid cover in an urban Wisconsin wetland (Hall \& Zedler 2010). These findings suggest that harvesting has the potential to be a viable restoration method for $T$. $\times$ glauca invaded wetlands.

\section{Typha $\times$ glauca in Great Lakes Coastal Wetlands}

Great Lakes coastal wetlands provide critical habitat for diverse plants communities (Albert \& Minc 2004), fish (Uzarski et al. 2005), migratory waterfowl, and shorebirds (Prince et al. 1992; Ewert \& Hamas 1995) and provide ecosystem services important to human well-being (Sierszen et al. 2012). Northern Lake Huron wetlands remain some of the highest quality, least disturbed coastal wetlands in the U.S. Great Lakes (Uzarski et al. unpublished data). Plant species in these ecosystems tend to sort into three distinct moisture dependent zones (wet meadow, emergent marsh, and submergent marsh). Characteristically, the wet-meadow is dominated by sedges (Carex stricta, C. aquatilis, C. lacustris) and blue-joint grass (Calamagrostis canadensis); the emergent marsh by bulrushes (Schoenoplectus acutus, S. pungens), spike rushes (Eleocharis spp.), rushes (Juncus spp.), and cattails (T. latifolia); and the submergent marsh by pondweeds (Potamogeton spp.), water-lilies (Nymphaea odorata and Nuphar spp.), and bladderworts (Utricularia spp.) (Albert et al. 2005). Presently, these wetlands are undergoing widespread macrophyte invasions (Lishawa et al. 2010; Tulbure \& Johnston 2010). Prolonged low water levels in the Great Lakes since 2000 (NOAA 2013) have reduced wave energy and exposed mud flats along the gently sloping shorelines (Albert et al. 2013), stimulating the establishment and proliferation of invasive plants (Tulbure et al. 2007). Predicted future water level declines associated with climate change (Angel \& Kunkel 2010) will likely exacerbate invasion.

Typha $\times$ glauca (hereafter Typha) is invading highly disturbed and otherwise intact, diverse, and high-quality Great Lakes coastal wetlands (Lishawa et al. 2010). Once established,
Typha is a superior competitor, spreading rapidly via rhizome expansion (Boers \& Zedler 2008), and tolerating variable water levels (Harris \& Marshall 1963). Because it is many times more productive than the native plants it replaces, deep organic sediments accrue in Typha stands accompanied by changes in microbial communities, soil nutrients, and biogeochemical cycling (Angeloni et al. 2006; Tuchman et al. 2009; Lishawa et al. 2013; Lishawa et al. 2014). Dead standing culms persist and accumulate as slowly decomposing aboveground litter (Vaccaro et al. 2009), preventing the penetration of light, buffering soil surface temperatures, and resulting in reduced plant diversity (Larkin et al. 2012). The effects of Typha on floristic and edaphic factors vary temporally. Mitchell et al. (2011) found that litter increased within 10 years, plant diversity decreased after 15 years, and soil organic matter (SOM) increased between 10 and 35 years following Great Lakes coastal wetland invasion. Similarly, Lishawa et al. (2014) found Typha stand-age negatively correlated with plant diversity and positively correlated with SOM. Furthermore, seed banks in older and highly disturbed Typha stands may be more depleted of native species than younger stands (Frieswyk \& Zedler 2006; Hall \& Zedler 2010). Thus, we expect that passive restoration (i.e. no additional planting) will promote more diverse plant community recovery in recently invaded wetlands.

We are unaware of any investigations of Typha restoration or seed bank studies in northern Great Lake coastal wetlands that tend to have high floristic quality (FQI) and low disturbance. In a Typha-invaded northern Great Lake coastal wetland, we asked: (1) How do harvest-restoration methods and time since invasion affect plant community response? and, (2) Do seed banks of more recently invaded stands have a higher capacity for passive restoration than those invaded for longer periods? We experimentally implemented two restoration treatments (aboveground and belowground biomass harvest) in Typha stands of two ages (old > 30 years; young $<20$ years) and evaluated plant community response over 3 years (1-year pre-treatment and 2-years post-treatment). Additionally, we conducted an experimental seed bank study investigating seedling emergence from field-collected sediments exposed to three water levels.

We hypothesized that $(\mathrm{H} 1)$ both restoration treatments would increase native plant diversity compared to controls, and belowground harvest would yield the greatest increase in diversity by removing rhizomes which can resprout following aboveground harvesting, (H2) young stands would have greater capacity for native plant community recovery than old stands, as indicated by a more diverse plant response, and likewise, (H3) soil seed banks in younger stands would have higher diversity and density of emergent seedlings than those from older stands.

\section{Methods}

\section{Study Site}

We conducted experimental restoration and seed bank studies in Cheboygan Marsh, a Great Lakes lacustrine open-embayment wetland (Albert et al. 2005) on northern Lake Huron near the city of Cheboygan, Michigan (lat $45^{\circ} 39^{\prime} \mathrm{N}$, long $84^{\circ} 28^{\prime} \mathrm{W}$ ). As 
compared to the relatively oligotrophic wetlands characteristic of the region, Cheboygan Marsh has elevated sediment nutrient levels, likely resulting in part from the adjacent City of Cheboygan wastewater treatment facility and in part from internal nutrient loading (Tuchman et al. 2009; Lishawa et al. 2010). Typha first established in Cheboygan marsh in the late 1940s and by 2010 over $62 \%$ of the 23 ha wetland was dominated by Typha (Lishawa et al. 2013). Within the invaded portion of the marsh, Typha is highly dominant, making up greater than $99 \%$ of aboveground biomass (Angeloni et al. 2006; Tuchman et al. 2009).

\section{Field Experiment}

During 2011-2013, we implemented a Typha management experiment testing the effects of stand-age (two levels) and restoration treatment (three levels). Using Typha stand-age maps created by aerial photo interpretation between 1963 and 2010 (Lishawa et al. 2013), we identified polygons of similar areas from two age classes (hereafter stands), old ( $>30$ years; $6.37 \mathrm{ha}$ ) and young (<20 years; $6.41 \mathrm{ha})$. We used a 2 -stand $\times 3$-treatment factorial design with four replicates, for a total of 24 plots; within each stand, we randomly assigned twelve $16-\mathrm{m}^{2}$ plots $(4 \times 4 \mathrm{~m})$ to one of three restoration treatments (aboveground harvest, belowground harvest, or control). We established plots in July 2011 and implemented treatments in August 2011. Water levels were below the sediment surface in all plots at the time of harvest. Aboveground harvest treatments consisted of cutting all stems at the sediment surface using an aquatic weed-wacker (Weeders Digest LLC, New Hope, MN, U.S.A.) and removing biomass and all standing litter from the plot. Belowground harvest consisted of aboveground harvesting followed by hand removal of all rhizomes from the sediment. Hand removal was accomplished by cutting organic sediments into approximately $0.25-\mathrm{m}^{2}$ blocks, removing rhizomes, and returning all non-rhizome material to the plot. To isolate our treatment areas and prevent translocation of nutrients and carbohydrates from outside plots, in 2011 and 2012 we severed belowground connections along all plot perimeters by cutting through roots and rhizomes using heavy-duty ice scrapers. Within each $16-\mathrm{m}^{2}$ plot, we established four $1-\mathrm{m}^{2}$ subplots located $0.5 \mathrm{~m}$ from the perimeter at plot corners.

In mid-July of each year (2011, 2012, 2013), we sampled the vegetation in each subplot by assigning aerial cover values $(<1-100 \%)$ for total vegetative cover, detritus, and for each plant species. Additionally, we recorded the presence of all plant species within $16-\mathrm{m}^{2}$ plots. Total species richness in the plot and the mean cover value of the four subplots were used for analysis. In 2011, we estimated root and rhizome biomass by collecting sediment subsamples from the belowground treatment plots $\left(25 \mathrm{~cm}^{2}\right.$ surface area $\times$ maximum rooting zone depth), washing sediment, separating roots from rhizomes, and oven drying samples. In 2011, aboveground Typha biomass was estimated for aboveground and belowground plots by subsampling aboveground biomass from $25-\mathrm{cm}^{2}$ quadrats, oven drying, and weighing the dry biomass. We calculated post-treatment aboveground biomass by collecting 50 culms of varied heights throughout Cheboygan Marsh and creating a stem height-to-dry biomass allometric equation $\left(g=0.5265 \mathrm{e}^{1.751 * \text { height }(\mathrm{m})} ; r^{2}=0.81\right)$. We measured the heights of Typha stems in each subplot in 2012 and 2013 and calculated biomass values using this equation. In late July 2012, we measured light penetration using a LI-189 Quantum sensor (LI-COR Inc., Lincoln, NE, U.S.A.). At each subplot center, we recorded photosynthetically active radiation (PAR, $\mu \mathrm{mols} \cdot \mathrm{s}^{-1} \cdot \mathrm{m}^{-2}$ ) at $2.0 \mathrm{~m}, 1.0 \mathrm{~m}, 0.5 \mathrm{~m}$, and $0.0 \mathrm{~m}$ (sediment surface). Mean 2.0-m PAR was considered 100\% light for each plot. We estimated light penetration through the canopy for each plot by averaging the four subplot PAR values at each height and relativized them by the mean 2.0-m PAR value.

\section{Seed Bank Experiment}

We used the seedling emergence method (van der Valk \& Davis 1978) to estimate seed bank composition within the old and young Typha stands. In July 2011, we collected three 5-cm deep sediment plugs with a bulb planter from each $16-\mathrm{m}^{2}$ field plot and composited subsamples. Sediment samples were cold stratified by storing them at $4^{\circ} \mathrm{C}$ from July 2011 to June 2012 when the experiment began. We removed detritus, rhizomes, and roots, composited within-stand samples, and thoroughly homogenized the sediments by hand. We spread a $1-\mathrm{cm}$ thick subsample of homogenized sediment over the surface of $10 \mathrm{~cm}$ of autoclave sterilized sand in $9.5-\mathrm{cm}$ diameter pots $\left(70.9-\mathrm{cm}^{3}\right.$ sediment per/pot). We randomly assigned pots to three different water level treatments (relative to soil surface): high $(+5$ $\mathrm{cm})$, moist $(0 \mathrm{~cm})$, or low $(-5 \mathrm{~cm})$. Four replicates of each stand $\times$ water level treatment were tested (24 total replicates). In June 2012, experimental pots were randomly placed in an environmental growth chamber under a fluctuating light and temperature regime approximating June conditions in the northern Great Lakes region: 16 hours light at $22.5^{\circ} \mathrm{C}, 8$ hours dark at $12.5^{\circ} \mathrm{C}$. Throughout the 6 -month study period, water levels were maintained twice a week and every 2 weeks pot locations were re-randomized and seedlings were identified and counted. Positively identified seedlings were removed from the pots, and unidentified seedlings were allowed to grow until identification was possible.

\section{Statistical Analysis}

Subplots within each plot were averaged and extrapolated to the plot level. We evaluated the effects of stand and year on plant community and environmental variables (Shannon diversity $\left[\mathrm{H}^{\prime}\right]$, species richness, Typha dominance [\% of total veg. cover], aboveground biomass $\left[\mathrm{g} / \mathrm{m}^{2}\right]$, belowground biomass $\left[\mathrm{g} / \mathrm{m}^{2}\right]$, and \% light reduction) and change in plant community variables between pre- and post-treatment using repeated measures analysis of variance (ANOVA). We assessed differences between treatments within years using Tukey's honestly significant differences test (HSD). Using indicator species analysis (ISA; Dufrene \& Legendre 1997), we evaluated correspondence of individual species with stand (old, young) and treatment (above, below, control) across the 3 years of the study (2011, 2012, 2013). Indicator values of plant species were tested via Monte-Carlo simulation using 1000 permutations. We tested the 
effects of year, stand, and treatment on multivariate plant communities using permutational multivariate analysis of variance (PERMANOVA; Anderson 2001). We used nonmetric multidimensional scaling (NMDS) ordination to characterize plant community differences by stand (old, young) and treatment (aboveground harvest, total harvest, control) and to evaluate associated variables as vectors (McCune \& Grace 2002). Dissimilarity between plots was based on Bray-Curtis distances, plots were constructed using two dimensions, and measured variables were tested for significance as vectors by permutation procedure (10,000 replicate permutations): species richness (richness), $\mathrm{H}^{\prime}$, percent unvegetated (unveg), percent vegetated (veg), detritus cover (detritus), Carex spp. cover (Carex), Juncus cover (Juncus), Typha cover (Typha), and water depth (water).

In the seed bank experiment, we tested the effects of Typha stand-age (old, young), experimental water treatments (low, moist, high), and age $\times$ water level on seed bank $\mathrm{H}^{\prime}$, species richness, FQI (Herman et al. 2001), stem density (\#/pot), Typha density (\#/pot), and Carex spp. density (\#/pot) using ANOVA with Tukey's HSD test.

All statistical analyses were conducted using R 2.12.1 (R Development Core Team 2009) with the labdsv package used for ISA (Roberts 2012) and the vegan package used for NMDS (Oksanen et al. 2006).

\section{Results}

\section{Pre-treatment Plant Communities}

In 2011 pre-treatment, 28 plant species occurred across the 24 plots: 7 graminoids, 14 forbs, 1 aquatic, 5 woody species, and Typha (Table S1). There were no statistical differences by stand-age or by random treatment assignment among $\mathrm{H}^{\prime}$, species richness, Typha dominance (\% of total vegetation cover), or aboveground biomass (Table 1; Fig. 1). However, we found significantly greater root and rhizome biomass in old Typha stands than in young stands: root-old, (mean $\pm \mathrm{SE}$; $\left.\mathrm{g} / \mathrm{m}^{2}\right) \quad 4,516 \pm 637$, root-young, 2,609 $\pm 724 \quad(p<0.05)$; and rhizome-old, 2,678 \pm 70 , rhizome-young, 1,682 \pm 391 $(p<0.05)$. ISA revealed that a single species, Symphyotrichum puniceum, was indicative of old stands (IV 63.1\%; $p=0.04$; Table S2). Additionally, we found slight but significantly greater Cyperaceae species richness in young stands than in old stands (Table 2). NMDS illustrated some clustering of pre-treatment young plot and old plot communities in multivariate space and correlations with several variables: water $\left(r^{2}=0.41, p<0.01\right)$; richness $\left(r^{2}=0.72 ; p<0.01\right)$; Carex $\left(r^{2}=0.26 ; p=0.03\right) ; \mathrm{H}^{\prime}$ $\left(r^{2}=0.64 ; p<0.01\right)$; and Typha $\left(r^{2}=0.29 ; p=0.03\right)$; (Fig. 2A). However, PERMANOVA revealed no statistical difference between pre-treatment plant communities by age, assigned treatment, or age $\times$ treatment (Table 3 ).

\section{Plant Community Response to Restoration}

Species richness nearly doubled from pre-treatment sampling to 53 species in post-year 2. Over the 3-year study, a total of 63 species were identified across all 24 plots (Table S1).
Table 1. Results from repeated measures ANOVA model testing for effects of sampling year (2011, 2012, and 2013), treatment (aboveground, belowground, and control), and stand-age (old and young) on Typha relative dominance, Typha cover (\%), total vegetation cover (\%), species richness, plant diversity $\left(\mathrm{H}^{\prime}\right)$, and aboveground biomass. $\mathrm{MS}=$ mean squares error.

\begin{tabular}{|c|c|c|c|c|c|}
\hline $\begin{array}{l}\text { Response } \\
\text { Variable }\end{array}$ & Source & $d f$ & $M S$ & $F$ & $p$ Value \\
\hline \multirow{8}{*}{$\begin{array}{l}\text { Typha } \\
\text { dominance }\end{array}$} & Treatment & 2 & 1.23 & 35.06 & $<0.001$ \\
\hline & Stand-age & 1 & 0.05 & 1.51 & 0.23 \\
\hline & Treatment $\times$ age & 2 & 0.02 & 0.53 & 0.60 \\
\hline & Error $^{\mathrm{a}}$ & 18 & 0.04 & & \\
\hline & Year & 1 & 0.87 & 38.69 & $<0.001$ \\
\hline & Year $\times$ treatment & 2 & 0.35 & 15.36 & $<0.001$ \\
\hline & Year $\times$ age & 1 & & 0.03 & 0.87 \\
\hline & Error $^{\mathrm{b}}$ & 42 & 0.02 & & \\
\hline \multirow{7}{*}{$\begin{array}{l}\text { Total } \\
\text { vegetation } \\
\text { cover }\end{array}$} & Treatment & 2 & 1604.44 & 20.01 & $<0.001$ \\
\hline & Stand-age & 1 & 30.46 & 0.38 & 0.55 \\
\hline & Treatment $\times$ age & 2 & 42.53 & 0.53 & 0.60 \\
\hline & Error $^{\mathrm{a}}$ & 18 & 80.20 & & \\
\hline & Year & 1 & 4914.00 & 51.43 & $<0.001$ \\
\hline & Year $\times$ treatment & 2 & 856.40 & 8.96 & $<0.001$ \\
\hline & Year $\times$ age & 1 & 1.10 & 0.92 & 0.92 \\
\hline \multirow[t]{8}{*}{ Richness } & Treatment & 2 & 127.93 & 4.44 & 0.03 \\
\hline & Stand-age & 1 & 33.35 & 1.16 & 0.30 \\
\hline & Treatment $\times$ age & 2 & 25.18 & 0.87 & 0.43 \\
\hline & Error $^{\mathrm{a}}$ & 18 & 28.80 & & \\
\hline & Year & 1 & 363.00 & 48.07 & $<0.001$ \\
\hline & Year $\times$ treatment & 2 & 24.94 & 3.30 & $<0.05$ \\
\hline & Year $\times$ age & 1 & 16.33 & 2.16 & 0.15 \\
\hline & Error $^{b}$ & 42 & 28.80 & & \\
\hline \multirow[t]{8}{*}{$\mathrm{H}^{\prime}$} & Treatment & 2 & 5.11 & 16.45 & $<0.001$ \\
\hline & Stand-age & 1 & 0.04 & 0.13 & 0.73 \\
\hline & Treatment $\times$ age & 2 & 0.02 & 0.05 & 0.95 \\
\hline & Error $^{\mathrm{a}}$ & 18 & 0.31 & & \\
\hline & Year & 1 & 4.42 & 39.70 & $<0.001$ \\
\hline & Year $\times$ treatment & 2 & 1.36 & 12.21 & $<0.001$ \\
\hline & Year $\times$ age & 1 & 0.10 & 0.89 & 0.35 \\
\hline & Error $^{\mathrm{b}}$ & 42 & & & \\
\hline \multirow{6}{*}{$\begin{array}{l}\text { Aboveground } \\
\text { biomass }\end{array}$} & Treatment & 1 & 234,342 & 5.10 & 0.04 \\
\hline & Stand-age & 1 & 36,570 & 0.80 & 0.38 \\
\hline & $\begin{array}{c}\text { Treatment } \times \text { age } \\
\text { Error }^{\mathrm{a}}\end{array}$ & 1 & 216,893 & 4.72 & 0.04 \\
\hline & Year & 1 & $4,355,801$ & 41.78 & $<0.001$ \\
\hline & Year $\times$ treatment & 2 & 813,246 & 3.90 & 0.03 \\
\hline & Year $\times$ age & 1 & 28,554 & 0.27 & 0.60 \\
\hline
\end{tabular}

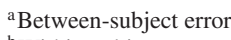

${ }^{\mathrm{b}}$ Within-subject error.

In the 2 years following treatment, species richness and aboveground Typha biomass varied by Typha stand-age; old stands had both greater richness (old: 12.71 \pm 1.21 ; young: $10.17 \pm 1.41$ species $/ \mathrm{m}^{2} ; p=0.028$ ) and greater Typha biomass (old: $407.5 \pm 101.6$; young: $309.1 \pm 80.2 \mathrm{~g} / \mathrm{m}^{2} ; p=0.033$ ) than young stands (Table 1). Neither $\mathrm{H}^{\prime}$ nor Typha dominance showed a stand-age effect $(p=0.80, p=0.21$, respectively; Table 1).

Belowground harvest significantly altered a suite of plant community measures in post-year 1 and differences persisted in post-year 2 (Tables $1 \& 2$; Fig. 1). In both years, $\mathrm{H}^{\prime}$ was greater than either aboveground harvest and control treatments (both $p<0.05$ ). Species richness more than doubled from 

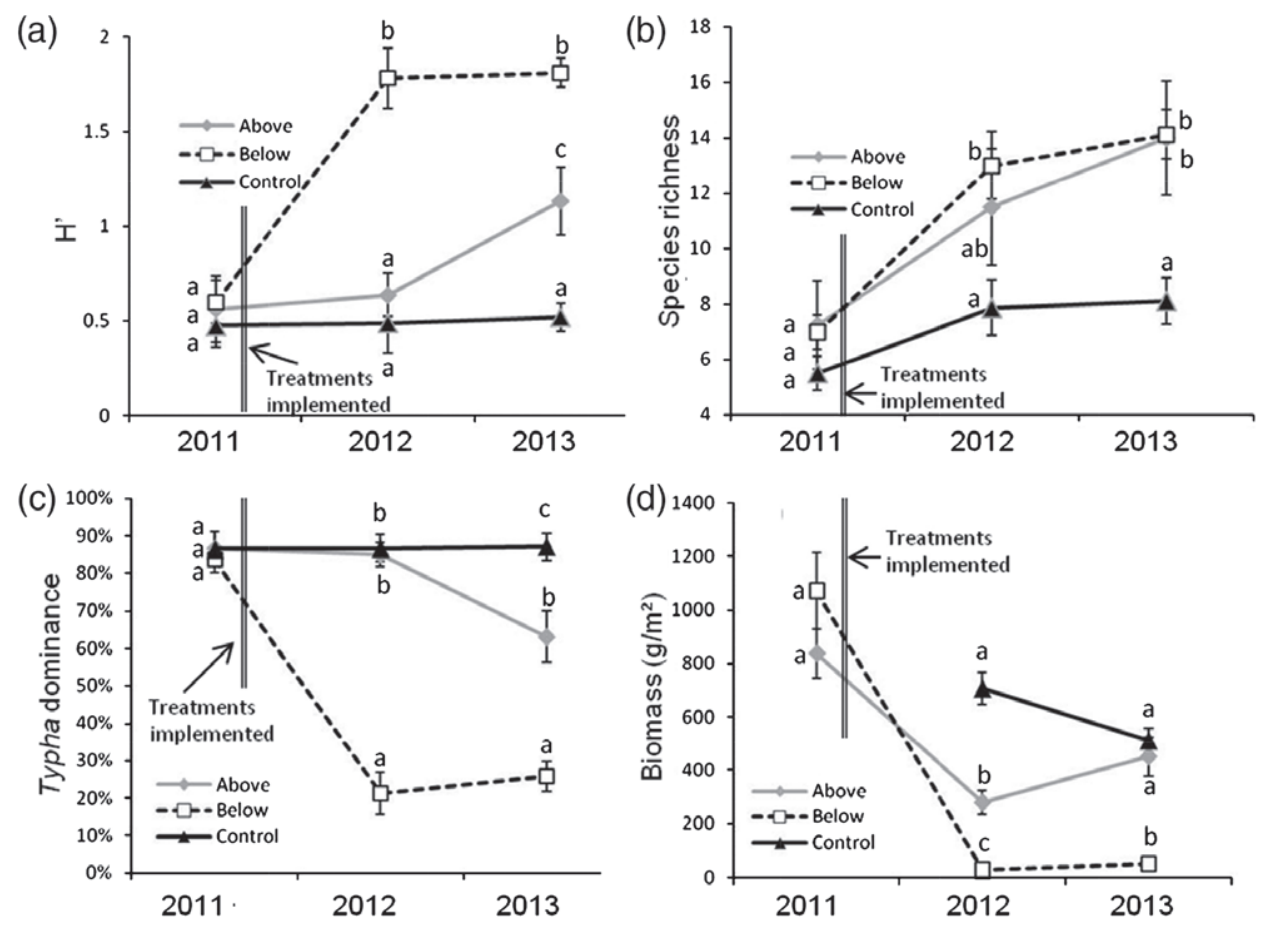

Figure 1. Four measures of vegetation response to experimental Typha management, Shannon diversity $\left(\mathrm{H}^{\prime}\right)(\mathrm{A})$, species richness (B), Typha dominance (\% of total cover) (C), and aboveground biomass $\left(\mathrm{g} / \mathrm{m}^{2}\right)$ (D) to three treatments (aboveground harvest, belowground harvest, and control) over 3 years, pre-treatment (2011) and 2 years following treatment (2012 and 2013) at Cheboygan Marsh. Within each year, treatments that do not share a common letter indicate significant differences (Tukey HSD).

Table 2. Year-specific plant species richness responses to restoration treatments (mean number of species per 16- $\mathrm{m}^{2} \mathrm{plot}[\mathrm{SE}]$ ).

\begin{tabular}{|c|c|c|c|c|c|c|c|c|}
\hline Year-Treatment ${ }^{a}$ & Total Richness & Native & Non-native & Woody & Forbs & Cyperaceae & Juncaceae & Poaceae \\
\hline P T Y & $7.0(0.5)$ & $5.8(0.5)$ & $1.2(0.0)$ & $0.6(0.0)$ & $4.0(0.2)$ & $1.2(0.2)^{\mathrm{B}}$ & $0.0(0.0)$ & $0.0(0.0)$ \\
\hline PY1 A & $11.5(6.0)^{\mathrm{ab}}$ & $9.6(2.0)$ & $1.6(0.3)$ & $0.9(0.3)^{\mathrm{ab}}$ & $5.1(1.2)$ & $1.6(0.3)^{\mathrm{a}}$ & $0.8(0.3)^{\mathrm{a}}$ & $0.9(0.2)$ \\
\hline PY1 B & $13.0(1.2)^{\mathrm{b}}$ & $11.0(1.1)$ & $1.4(0.2)$ & $0.1(0.1)^{\mathrm{b}}$ & $4.5(0.6)$ & $3.1(0.5)^{b}$ & $2.3(0.3)^{b}$ & $0.8(0.3)$ \\
\hline PY2 C & $7.8(1.0)^{A}$ & $6.4(0.9)^{A}$ & $1.4(0.2)$ & $0.1(0.1)$ & $5.1(0.7)$ & $0.8(0.3)^{A}$ & $0.0(0.0)^{A}$ & $0.3(0.3)$ \\
\hline
\end{tabular}

Plants grouped into geographic origin (native, non-native), form (woody, forbs), and dominant wetland plant families (Cyperaceae, Juncaceae, Poaceae). Within-year (PT, pre-treatment; PY1, post-year 1; PY2, post-year 2) statistical differences between treatments (O, old; Y, young; C, control; A, above; B, below) represented by non-overlapping superscript letters (Tukey HSD).

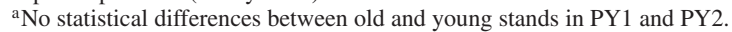

pre-treatment $(7.00 \pm 0.63)$ to post-year $1(13.00 \pm 1.22)$ and post-year $2\left(14.13 \pm 0.90\right.$ species $\left./ \mathrm{m}^{2}\right)$ and was significantly greater than in control plots both years following treatment (both $p<0.05$ ). Typha dominance and aboveground Typha biomass were lower than aboveground and control treatments both years (both $p<0.05$ ). Cyperaceae and Juncaceae species richness were greater (both $p<0.05$ ) in belowground plots than in control or aboveground plots in both years following harvest (Table 2). ISA analysis revealed that in post-year 1, six species were significant indicators of belowground harvest treatment, Juncus nodosus (IV 93.4\%; $p<0.001$ ), Schoenoplectus tabernaemontani (IV 93.2\%; $p<0.001$ ), Ranunculus sceleratus (IV 92.7\%; $p<0.001$ ), J. alpinoarticulatus (IV 84.2\%; $p<0.01$ ), Sparganium eurycarpum (IV 79.1\%; $p<0.01$ ), and Alisma triviale (IV 70.7\%; $p=0.02$ ). In post-year 2 , five species were indicative, J. nodosus (IV 85.2\%; $p<0.01$ ), S. tabernaemontani (IV 84.9\%; $p<0.01$ ), J. alpinoarticulatus (IV 83.8\%; $p<0.01$ ), A. triviale (IV 70.7\%; $p=0.02$ ), and S. acutus (IV $70.7 \% ; p=0.02$; Table S2).

Compared to controls, aboveground harvest reduced aboveground Typha biomass in post-year $1(p<0.05)$ but did not differ in post-year 2 (Fig. 1D). However, other aboveground harvest treatment effects did not emerge until post-year 2. In post-year 1, aboveground harvest had no significant effect on $\mathrm{H}^{\prime}$, species richness, or Typha dominance, but in post-year 2, each of these factors differed between aboveground harvest and 

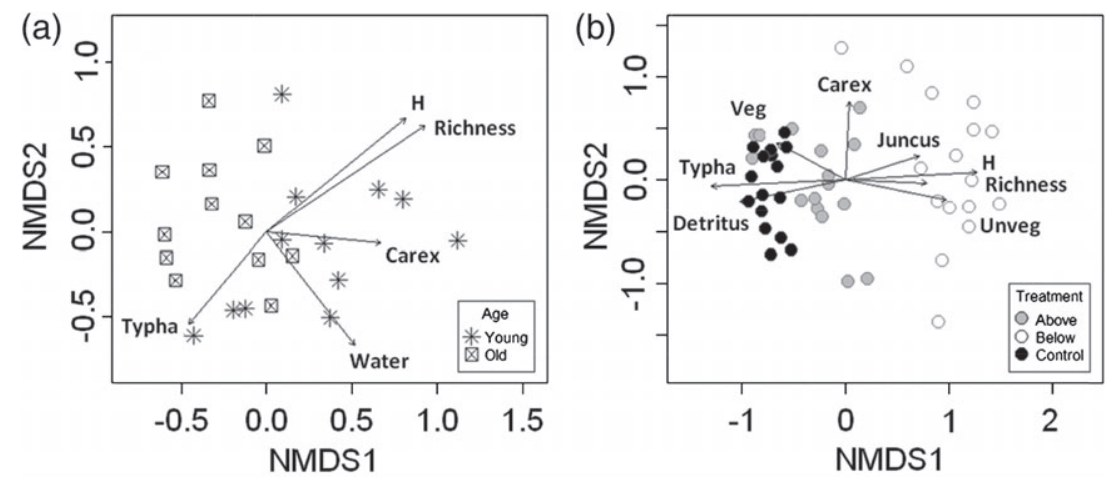

Figure 2. Nonmetric multidimensional scaling ordination of plot-level plant community data from Cheboygan Marsh. Points close together in ordination space indicate that plots were similar in plant community composition; (A) pre-treatment (2011) data $(n=24)$ illustrating Typha stand-age (old: >30 years; young: $<20$ years) and (B) post-treatment data $(2012$ and 2013; $n=48)$ highlighting differences between treatments (aboveground harvest, belowground harvest, control). Dissimilarity was based on Bray-Curtis distances, and plots were constructed using two dimensions. Fitted vector arrows are significant $(p<0.05$, by permutation procedure), and their length is proportional to their explanatory strength.

Table 3. Results of PERMANOVA (adonis function) testing the effects of year (2011, 2012, 2013), stand-age (old, young), and treatment (above, below, control) on multivariate plant communities. SS = sums of squares error.

\begin{tabular}{|c|c|c|c|c|c|c|c|c|c|c|c|c|c|c|c|}
\hline & \multicolumn{5}{|c|}{ All Years (2011-2013) } & \multicolumn{5}{|c|}{ Pre-treatment (2011) } & \multicolumn{5}{|c|}{ Post-treatment $(2012,2013)$} \\
\hline Year & 1 & 1.08 & 11.18 & 0.90 & 0.01 & - & - & - & - & - & 1 & 0.24 & 2.70 & 0.03 & 0.04 \\
\hline Treatment & 2 & 3.23 & 16.62 & 0.27 & 0.01 & 2 & 0.07 & 0.80 & 0.07 & 0.62 & 2 & 4.72 & 25.80 & 0.49 & 0.01 \\
\hline Year $\times$ age & 1 & 0.15 & 1.53 & 0.01 & 0.20 & - & - & - & - & - & 1 & 0.10 & 1.12 & 0.01 & 0.34 \\
\hline Year $\times$ treatment & 2 & 1.06 & 5.45 & 0.09 & 0.01 & - & - & - & - & - & 2 & 0.56 & 3.08 & 0.06 & 0.01 \\
\hline
\end{tabular}

controls (all $p<0.05$; Fig. 1). Aboveground harvest increased species richness from $7.25( \pm 4.53)$ pre-treatment to 11.5 $( \pm 5.95)$ post-year 1 and $14.00( \pm 5.83)$ post-year 2 (Fig. 1B), and richness was significantly greater in treatment than in control plots in post-year 2 ( $p<0.05$; Table 2; Fig. 1B). Native and Cyperaceae species richness were also greater than the control in post-year $2(p<0.05$; Table 2$)$. The native grass Calamagrostis canadensis was a significant indicator of aboveground treatment in both post-year 1 (IV: $74.6 \% ; p=0.02$ ) and post-year 2 (IV: $82.8 \% ; p=0.01$; Table S2).

In both years following treatment, multivariate community assemblage differed by year, treatment, year $\times$ treatment, and stand-age $\times$ treatment (PERMANOVA; Table 3). Treatment plots clustered in mulitvariate space and were correlated with several variables (Fig. $2 \mathrm{~B})$ : unveg $\left(r^{2}=0.46, p<0.01\right)$; veg $\left(r^{2}=0.26, p<0.01\right)$; detritus $\left(r^{2}=0.50 ; p<0.01\right)$; richness $\left(r^{2}=0.29 ; p<0.01\right) ;$ Carex $\left(r^{2}=0.27 ; p<0.01\right) ; \mathrm{H}\left(r^{2}=0.75\right.$; $p<0.01)$; Juncus $\left(r^{2}=0.26 ; p<0.01\right)$; and Typha $\left(r^{2}=0.78\right.$; $p<0.01)$.

\section{Light Penetration Response to Restoration}

In post-year 1 , the percentage of PAR penetration differed significantly by treatment at all three heights above the marsh sediment surface $(1.0 ; 0.5 ; 0.0 \mathrm{~m})$. Light was almost entirely prevented from reaching the sediment surface in

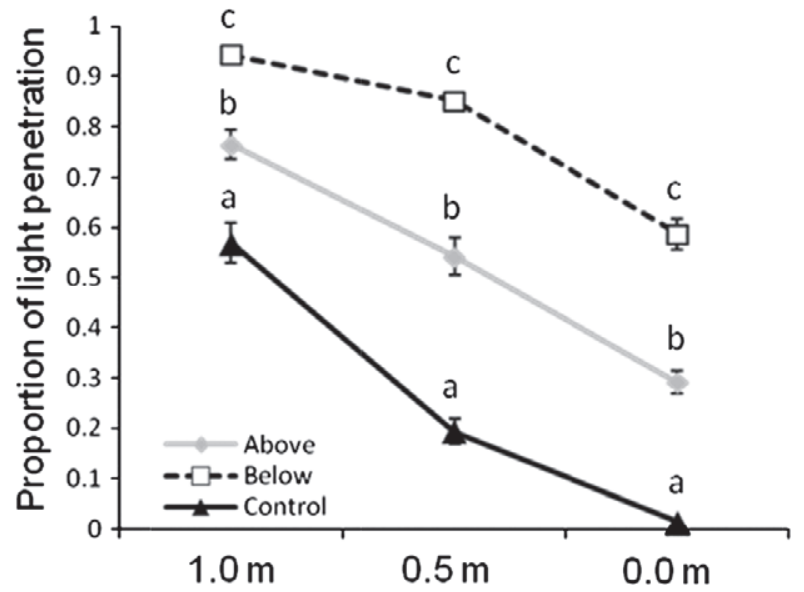

Figure 3. Penetration of PAR in 2012, 1 year after conducting three restoration treatments (aboveground harvest, belowground harvest, and control) at three heights above the marsh sediment surface $(1 ; 0.5 ; 0 \mathrm{~m})$ at Cheboygan Marsh. Within each height, non-overlapping letters (a, b, c) indicate significant differences between treatments (Tukey HSD).

the control plots $(1.37 \pm 0.15 \%$ light penetration); whereas belowground harvest dramatically increased light penetration $(58.60 \pm 3.01 \%)$ and aboveground harvest plots had an intermediate effect (29.13 $\pm 2.20 \%$; Fig. 3$)$. 
Table 4. Effects of Typha stand-age (old: $>30$ years; young: $<20$ years) and experimental water treatments (low: $-5 \mathrm{~cm}$; moist sediment: $0 \mathrm{~cm}$ ) on seed bank Shannon diversity $\left(\mathrm{H}^{\prime}\right)$, species richness, floristic quality, stem density, Typha density, and Carex spp. density at Cheboygan Marsh. SS = sums of squares error.

\begin{tabular}{|c|c|c|c|c|c|c|c|c|c|c|c|c|}
\hline Characteristic & \multicolumn{4}{|c|}{ Age } & \multicolumn{4}{|c|}{ Water Level } & \multicolumn{4}{|c|}{ Age $\times$ Water } \\
\hline Shannon diversity $\left(\mathrm{H}^{\prime}\right)$ & 1 & 5.80 & 70.25 & $<0.001$ & 1 & 0.17 & 2.02 & 0.18 & 1 & 0.05 & 0.55 & 0.46 \\
\hline FQI & 1 & 35.70 & 9.77 & $<0.001$ & 1 & 9.78 & 2.67 & 0.13 & 1 & 31.08 & 8.51 & 0.01 \\
\hline Stem density (\# stems) & 1 & 2756.25 & 49.89 & $<0.001$ & 1 & 182.25 & 3.30 & 0.09 & 1 & 20.25 & 0.58 & 0.56 \\
\hline Typha density (\# stems) & 1 & 0.06 & 0.01 & 0.91 & 1 & 27.56 & 6.15 & 0.02 & 1 & 0.56 & 0.13 & 0.73 \\
\hline
\end{tabular}

\section{Seed Bank Analyses}

The high water $(+5-\mathrm{cm})$ treatment prevented any seedlings from emerging in all but two replicates (one old, one young) and was, therefore, eliminated from statistical analyses. Stand-age impacted several important measures of seed bank composition, with young stands exhibiting significantly greater $\mathrm{H}^{\prime}$, seedling density, richness, Carex spp. density, and FQI than old stands (all $p<0.05$; Table 4; Fig. 4). Water level treatment impacted Typha seedling emergence; moist $(0 \mathrm{~cm})$ had significantly greater Typha seedling density $(2.75 \pm 0.98$ seedlings/pot $)$ than the low $(-5-\mathrm{cm})$ treatment $(0.13 \pm 0.13$ seedlings/pot; $p=0.03$; Table 4; Fig. 4E). Age $\times$ water level significantly impacted FQI; old-moist treatment had significantly lower FQI than any other age $\times$ water level treatment $(p=0.01$; Table 4; Fig. 4F).

\section{Discussion}

Harvesting invasive plants achieved at least two desired ecological outcomes in our study (1) reducing Typha coverage, and (2) increasing native plant diversity. As predicted (H1), both aboveground and belowground (i.e. total biomass) harvest treatments increased native plant diversity, reduced Typha dominance and biomass, and increased light penetration in the 2 years following treatment. Belowground harvest had more immediate and greater impact on all of these measures likely resulting from the elimination of rhizomatous Typha and some release of buried seeds as a result of sediment disturbance. However, despite the robust native plant response, harvesting belowground biomass is not likely feasible at large-scales without specialized machinery due to the time intensity of the method (we spent $>32$ person-hours per $16-\mathrm{m}^{2}$ plot). Our results indicate that in similar upper Great Lakes coastal wetlands, a single harvest of aboveground Typha biomass alone will result in significant biodiversity and habitat value improvements, with the potential to more than double native plant species richness.

Typha aboveground biomass is viable for fuel pellet production (Cicek et al. 2006; Grosshans et al. 2012), and preliminary research indicates that it is also a suitable feedstock for biogas digestion (Lishawa et al. unpublished data). Second, we found that pre-treatment aboveground biomass in Cheboygan Marsh was greater than reported annual productivity of the bioenergy crop species Panicum virgatum (switchgrass) (Typha:
$9.54 \pm 0.87$ dry mass t/ha this study; $P$. virgatum: $8 \mathrm{dmt} / \mathrm{ha}$, McKendry 2002). Productivity varied following treatment, however. Harvesting biomass significantly reduced aboveground biomass 1 year following harvest, but in the second year following harvest, biomass did not differ from the control. Control biomass was also lower post-treatment, however, probably resulting from plot perimeter rhizome cutting. Our results indicate that repeated annual harvesting would likely maintain reduced Typha dominance but would yield diminishing quantities of biomass. Although feedstock viability and productivity values indicate the potential for linking restoration with bioenergy production, thorough economic analyses are necessary to assess regional feasibility. Examples of such analyses include evaluation of salt cedar and Russian olive in Washington State (Nackley et al. 2013) and switchgrass, hybrid poplar and willow in the northern Great Lakes region (Kells \& Swinton 2014). Furthermore, the ecosystem service benefits of harvesting invasive plants, such as potential biodiversity enhancement, greenhouse gas mitigation, and nutrient removal, should be included in future feasibility studies.

Prior to restoration treatments, old ( $>30$ years) and young (<20 years) Typha stands exhibited nearly indistinguishable aboveground plant community characteristics. These data support Mitchell et al.'s (2011) findings that Typha density, litter mass, $\mathrm{H}^{\prime}$, and species richness all varied with stand-age in a Great Lakes coastal wetland but did not differ significantly beyond 15 years post-invasion. We found that old Typha stands had greater belowground biomass than young stands and following treatment, aboveground Typha biomass re-growth was greater in old stands, likely owing to larger carbohydrate reserves. Despite this aboveground response, and counter to our expectations $(\mathrm{H} 2)$, native plant communities did not respond more vigorously to experimental harvest in younger stands. The complete removal of the Typha litter layer presumably eliminated differences between age classes as litter accumulation is the principal mechanism through which native plants are excluded from Typha-invaded wetlands (Farrer \& Goldberg 2009; Vaccaro et al. 2009; Larkin et al. 2012). We expect that over the long-term, faster recovery of aboveground Typha biomass in old stands would be accompanied by more rapid litter accumulation and concomitant depletion of native species diversity, although continued monitoring would be required to confirm this hypothesis. Additionally, it may be possible that the two age classes we identified had both surpassed an ecological 
(a)
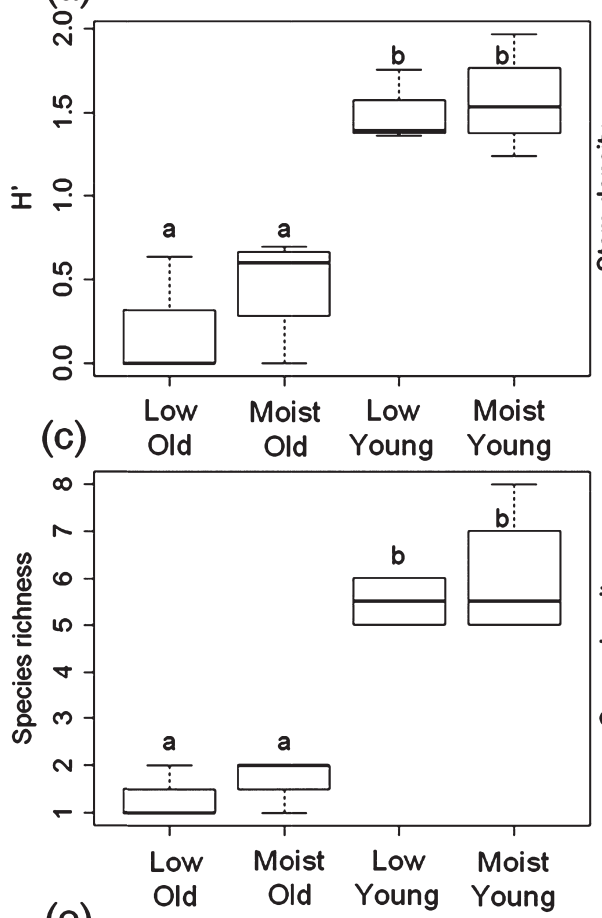

(e)

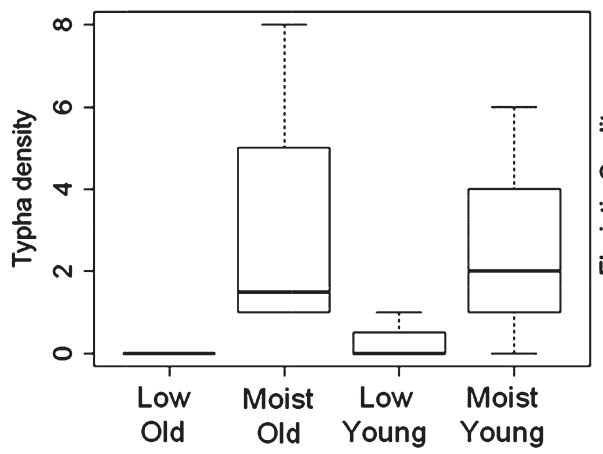

(b)
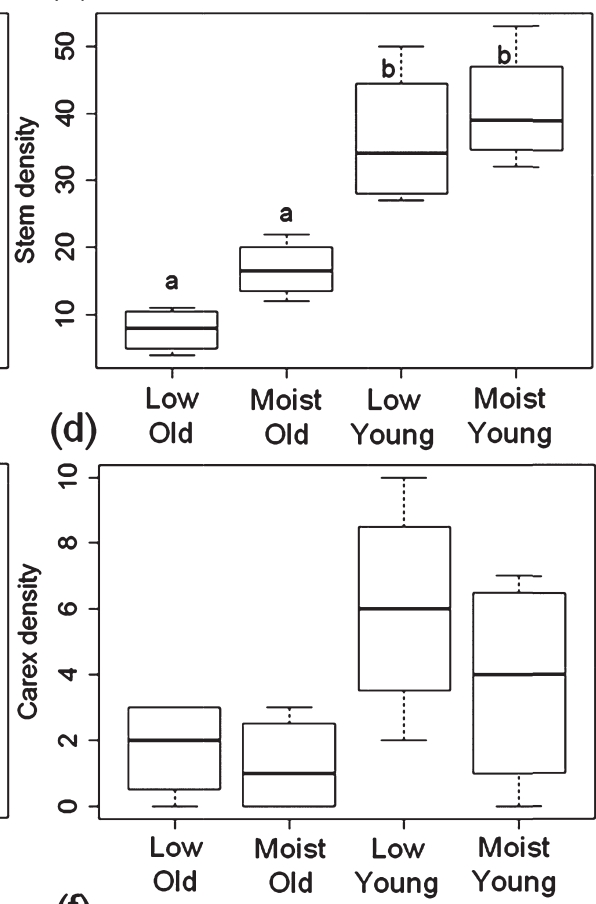

(f)

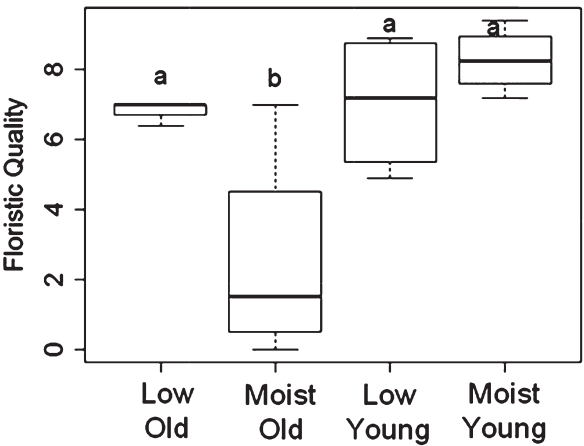

Figure 4. Measures of seed bank composition from old ( $>30$ years) and young ( $<20$ years) Typha stands exposed to two water level treatments low ( $-5 \mathrm{~cm})$ and moist sediment $(0 \mathrm{~cm})$; (A), Shannon diversity $\left(\mathrm{H}^{\prime}\right)$, (B) stem density, (C) species richness, (D) Carex density, (E) Typha density, and (F) Floristic quality. All measures reflect per-pot responses; each pot contained $71 \mathrm{~cm}^{3}$ of wetland sediment. Non-overlapping letters (a, b, c) indicate significant differences between treatments (Tukey HSD).

threshold, beyond which the impact of stand-age is muted. Testing our harvest treatments on more recent invasions $(<10$ years) may have resulted in more diverse community responses.

As predicted (H3), several measures of seed bank community composition were more robust in young stands than in the old stands including $\mathrm{H}^{\prime}$, richness, seedling density and Carex spp. density. Based on these data, higher diversity and abundance of native species in the experimental young plots in the field would be expected, but we did not see this response. This discrepancy may have resulted in part from the vegetative expansion of clonal species, although we did not differentiate between seedling and clonal resprouts. Despite the differences between our field harvest treatments and seed bank data, the young Typha stands evaluated in this study clearly had a more intact seed banks than old stands, and therefore greater plant community resilience (Frieswyk \& Zedler 2006). Additionally, we observed widespread flowering and seed production by native plants in our aboveground and belowground study plots, indicating that harvesting may have the potential to replenish the seed bank.

Our results indicate that harvesting Typha biomass is a viable alternative restoration practice to burning and herbiciding. In contrast with Hall and Zedler (2010), who used similar methods in a highly disturbed urban wetland and concluded that restoration required annual harvesting for many years with associated planting, we documented increasing ecological returns through 2 years following a single aboveground harvest. Our results indicate that there is strong potential for passive (i.e. no planting) restoration of native plant communities in sites with undisturbed hydrology and relatively diverse seed banks, such as within Great Lakes coastal wetlands along the shorelines of northern 
Lake Huron and the St. Marys River. Wetlands in this region are some of the highest quality in the Great Lakes (Uzarski et al. unpublished data) and are presently experiencing widespread invasion by Typha associated with low Great Lakes water levels (Lishawa et al. 2010). Although repeated harvesting would likely be required to maintain diversity over the long-term, management efforts could occur on 3 or more year rotations. We recommend larger scale implementation of above-ground harvest at or near the sediment surface in these wetland complexes to limit biomass accumulation which reinforces the invaded state. Additionally, there is a need to experimentally examine the effects of aboveground harvest on fish and bird habitat, ecosystem functions such as greenhouse gas flux, and the floral and ecological responses to annual and biennial harvesting in these ecosystems, as repeated harvesting may more accurately reflect bioenergy-focused management. While farm equipment has been used to manage Typha without affecting soil bulk density (Osland et al. 2011), care should be taken to avoid sediment disturbance and compaction, such as using harvesting equipment designed for wetland applications.

Management practices involving the utilization of invasive plant biomass for bioenergy may help to offset costs associated with ecological restoration (Miller \& Hobbs 2007; Jakubowski et al. 2010; Nackley et al. 2013; Quinn et al. 2013). While conceptually encouraging, it remains unclear under what circumstances harvesting invasive plants will achieve traditional ecological restoration goals like increased biodiversity and ecosystem function. Our findings illustrate that in the case of Typha $\times$ glauca, there is great potential for linking restoration and bioenergy production.

\section{Acknowledgments}

Funding came from EPA GLRI grant GL-00E00545. We thank D. Monks, K. Greene, E. Tuchman, M. Davern, E. Marcos, J. Albert, and B. Castillo for their Herculean efforts in the field and lab.

\section{LITERATURE CITED}

Albert DA, Minc LD (2004) Plants as regional indicators of Great Lakes coastal wetland health. Aquatic Ecosystem Health \& Management 7:233-247

Albert DA, Wilcox DA, Ingram JW, Thompson TA (2005) Hydrogeomorphic classification for Great Lakes coastal wetlands. Journal of Great Lakes Research 31:129-146

Albert DA, Cox DT, Lemein T, Yoon HD (2013) Characterization of Schoenoplectus pungens in a Great Lakes coastal wetland and a Pacific Northwestern estuary. Wetlands 33:445-458

Anderson MJ (2001) A new method for non-parametric multivariate analysis of variance. Austral Ecology 26:32-46

Angel JR, Kunkel KE (2010) The response of Great Lakes water levels to future climate scenarios with an emphasis on Lake Michigan-Huron. Journal of Great Lakes Research 36:51-58

Angeloni NL, Jankowski KJ, Tuchman NC, Kelly JJ (2006) Effects of an invasive cattail species (Typha x glauca) on sediment nitrogen and microbial community composition in a freshwater wetland. FEMS Microbiology Letters 263:86-92

Boers AM, Zedler JB (2008) Stabilized water levels and Typha invasiveness. Wetlands 28:676-685
Cicek N, Lambert S, Venema H, Snelgrove K, Bibeau E, Grosshans R (2006) Nutrient removal and bio-energy production from Netley-Libau Marsh at Lake Winnipeg through annual biomass harvesting. Biomass and Bioenergy 30:529-536

Dubbe DR, Garver EG, Pratt DC (1988) Production of cattail (Typha spp.) biomass in Minnesota, USA. Biomass 17:79-104

Dufrene M, Legendre P (1997) Species assemblages and indicator species: The need for a flexible asymmetrical approach. Ecological Monographs 67:345-366

Ewert DN, Hamas MJ (1995) Ecology of terrestrial migratory birds during migration in the Midwest. USFS NC-187. United States Forest Service, St. Paul, Minnesota

Farrer EC, Goldberg DE (2009) Litter drives ecosystem and plant community changes in cattail invasion. Ecological Applications 19:398-412

Frieswyk CB, Zedler JB (2006) Do seed banks confer resilience to coastal wetlands invaded by Typha x glauca? Canadian Journal of Botany-Revue Canadienne De Botanique 84:1882-1893

Grosshans RE, Gass P, Dohan R, Roy D, Venema HD, McCandless M (2012) Pages 51. Cattail harvesting for carbon offsets and nutrient capture: A "lake friendly" greenhouse gas project. The International Institute for Sustainable Development, Winnipeg, Canada

Hall SJ, Zedler JB (2010) Constraints on sedge meadow self-restoration in urban wetlands. Restoration Ecology 18:671-680

Hall SJ, Lindig-Cisneros R, Zedler JB (2008) Does harvesting sustain plant diversity in central Mexican wetlands. Wetlands 28:776-792

Harris SW, Marshall WH (1963) Ecology of water-level manipulations on a northern marsh. Ecology 44:331-343

Herman KD, Masters LA, Penskar MR, Reznicek AA, Wilhelm GS, Brodowicz WW, Gardiner KP (2001) Floristic quality assessment with wetland categories and examples of computer applications for the state of Michigan. Report 2001-17. Michigan Department of Natural Resources, Wildlife Division, Natural Heritage Program, Lansing

Jakubowski AR, Casler MD, Jackson RD (2010) Landscape context predicts reed canarygrass invasion: implications for management. Wetlands 30:685-692

Kells BJ, Swinton SM (2014) Profitability of cellulosic biomass production in the northern Great Lakes region. Agronomy Journal 106:397-406

Larkin DJ, Freyman MJ, Lishawa SC, Geddes P, Tuchman NC (2012) Mechanisms of dominance by the invasive hybrid cattail Typha $\times$ glauca. Biological Invasions 14:65-77

Lishawa SC, Albert DA, Tuchman NC (2010) Water level decline promotes Typha $\times$ glauca establishment and vegetation change in Great Lakes coastal wetlands. Wetlands 30:1085-1096

Lishawa SC, Treering DJ, Vail LM, Mckenna O, Grimm EC, Tuchman NC (2013) Reconstructing plant invasions using historical aerial imagery and pollen core analysis: Typha in the Laurentian Great Lakes. Diversity and Distributions 19:14-28

Lishawa SC, Jankowski KJ, Geddes P, Larkin DJ, Monks AM, Tuchman NC (2014) Denitrification in a Laurentian Great Lakes coastal wetland invaded by hybrid cattail (Typha $\times$ glauca). Aquatic Sciences 76:483-495, DOI: 10.1007/s00027-014-0348-5

McCune B, Grace JB (2002) Analysis of ecological communities. MjM Software Design, Gleneden Beach, Oregon

McKendry P (2002) Energy production from biomass (part 1): overview of biomass. Bioresource Technology 83:37-46

Miller JR, Hobbs RJ (2007) Habitat restoration — do we know what we're doing? Restoration Ecology 15:382-390

Mitchell ME, Lishawa SC, Geddes P, Larkin DJ, Treering D, Tuchman NC (2011) Time-dependent impacts of cattail invasion in a Great Lakes coastal wetland complex. Wetlands 31:1143-1149

Nackley LL, Lieu VH, Garcia BB, Richardson JJ, Isaac E, Spies K, Rigdon S, Schwartz DT (2013) Bioenergy that supports ecological restoration. Frontiers in Ecology and the Environment 11:535-540

National Oceanic and Atmospheric Administration 2013. Great Lakes Environmental Research Laboratory. www.glerl.noaa.gov/data/now/wlevels/levels. html (accessed 4 Dec 2013) 
Oksanen J, Kindt R, Legendre P, O'Hara RB (2006) vegan: Community ecology package. $\mathrm{R}$ package version 1.8-3. cran.r-project.org

Osland MJ, González E, Richardson CJ (2011) Restoring diversity after cattail expansion: disturbance, resilience, and seasonality in a tropical dry wetland. Ecological Applications 21:715-728

Prince HH, Padding PI, Knapton RW (1992) Waterfowl use of the Laurentian Great Lakes. Journal of Great Lakes Research 18:673-699

Quinn LD, Endres AB, Voigt TB (2013) Why not harvest existing invaders for bioethanol? Biological Invasions 16:1559-1566

R Development Core Team (2009) R: A language and environment for statistical computing. R Foundation for Statistical Computing, Vienna, Austria

Roberts DW (2012) labdsv: Ordination and multivariate analysis for ecology. R package version 1.5-0. cran.r-project.org

Sierszen ME, Morrice JA, Trebitz AS, Hoffman JC (2012) A review of selected ecosystem services provided by coastal wetlands of the Laurentian Great Lakes. Aquatic Ecosystem Health \& Management 15:92-106

Smith SG (1987) Typha: its taxonomy and the ecological significance of hybrids. Archiv für Hydrobiologie 27:129-138

Strayer DL, Eviner VT, Jeschke JM, Pace ML (2006) Understanding the longterm effects of species invasions. Trends in Ecology \& Evolution 21: $645-651$

Suding KN, Gross KL, Houseman GR (2004) Alternative states and positive feedbacks in restoration ecology. Trends in Ecology \& Evolution 19: $46-53$

Tuchman NC, Jankowski KJ, Geddes P, Wildova R, Larkin DJ, Goldberg DE (2009) Patterns of environmental change associates with Typha $\times$ glauca invasion in a Great Lakes coastal wetland. Wetlands 29: 964-975

Coordinating Editor: Kern Ewing
Tulbure MG, Johnston CA (2010) Environmental conditions promoting non-native Phragmites australis expansion in Great Lakes coastal wetlands. Wetlands 30:577-587

Tulbure MG, Johnston CA, Auger DL (2007) Rapid invasion of a Great Lakes coastal wetland by non-native Phragmites australis and Typha. Journal of Great Lakes Research 33:269-279

Uzarski DG, Burton TM, Cooper MJ, Ingram JW, Timmermans STA (2005) Fish habitat use within and across wetland classes in coastal wetlands of the five Great Lakes: development of a fish-based index of biotic integrity. Journal of Great Lakes Research 31:171-187

Vaccaro LE, Bedford BL, Johnston CA (2009) Litter accumulation promotes dominance of invasive species of cattails (Typha spp.) in Lake Ontario wetlands. Wetlands 29:1036-1048

van der Valk AG, Davis CB (1978) The role of seed banks in the vegetation dynamics of prairie glacial marshes. Ecology 59:322-335

Zedler JB (2009) Feedbacks that might sustain natural, invaded and restored states in herbaceous wetlands. Pages 236-258. In: Hobbs R, Suding K (eds) New models for ecosystem dynamics and restoration. Island Press, Washington, D.C.

\section{Supporting Information}

The following information may be found in the online version of this article:

Table S1. Frequency ( $\%$ of 24 plots) of plant species found in the field experiment prior to treatment (pre-treatment 2011) and post-treatment (post-year 1 and post-year 2). Presence of species in the seed bank experiment indicated with $x$.

Table S2. Results of indicator species analysis for plant species grouped by stand-age $(\mathrm{O}$, old; $\mathrm{Y}$, young) and treatment (A, above; B, below; $\mathrm{C}$, control). Only plant species which were significantly $(p<0.05)$ related to a group are listed. Indicator values represent the percentage of perfect indication for each group.

Received: 21 May, 2014; First decision: 1 July, 2014; Revised: 18 November, 2014; Accepted: 19 November, 2014; First published online: 6 January, 2015 